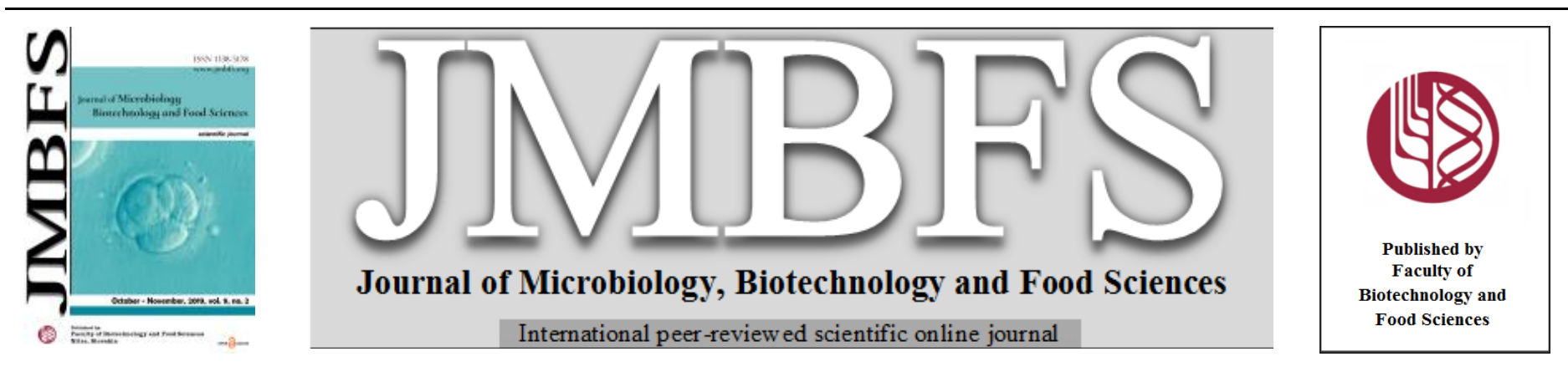

\title{
MULTIVARIATE STATISTICS OF FERTILITY PARAMETER FLUXES IN CEMENT-DUST-POLLUTED SOILS IN MFAMOSING, NIGERIA: IMPACT ON AGRICULTURE
}

\author{
Atim Asitok ${ }^{*}{ }^{1}$, Maurice Ekpenyong ${ }^{1}$ \& Sylvester Antai ${ }^{1}$ \\ Address(es): Dr. (Mrs.) Atim Asitok, \\ ${ }^{1}$ University of Calabar, Faculty of Biological Sciences, Department of Microbiology, Eta Agbo Road, 540242 Calabar, Cross River State, +234-80-37302627.
}

*Corresponding author: atimasitok@yahoo.com

doi: 10.15414/jmbfs.2020.9.4.781-789

\section{ARTICLE INFO}

Received 20. 9. 2018

Revised 11. 9. 2019

Accepted 24. 9. 2019

Published 3. 2. 2020

Regular article open $\mathcal{O}$ access

\begin{abstract}
This study investigated the impact of cement-dust pollution on the fertility status of agricultural soils to ascertain their health and suitability for cropping. Relevant soil nutrients and enzyme activities were determined from 12 control soil, 12 NPK-treated polluted soil and 12 un-amended polluted soil samples, using standard soil analytical and biochemical procedures. Soil microbial biomass-carbon was quantified by chloroform-fumigation-extraction (CFE) method. Cultivable aerobic bacterial count was determined on Tryptic Soy Agar (TSA) while cultivable fungal quantitation was performed on Czapek-Dox agar. Corn (Zea mays) yield served to evaluate pollutant effect on tested parameters. Principal component analysis (PCA) extracted two components, PC1 and PC2, from nine studied dependent variables (DVs) which explained $68.33 \%$ variability about the data. Number and membership of extracted components were confirmed by two clusters obtained by agglomerative hierarchical cluster analysis (AHCA). Multivariate analysis of covariance revealed significant effect of soil type on the combined DVs when the effect of the covariate (planting period) was controlled. One-way analysis of covariance (one-way ANCOVA) revealed non-significant effect of planting period but a significant main effect of soil type on corn yield when controlling for the effect of the covariate. Relative to control soil, per cent loss in corn yield was $55.69 \%$ in cement dustpolluted soil but reduced to $36.07 \%$ in polluted soils treated with NPK. The research findings have shown that cement dust pollution significantly reduced corn yield and the stress may persist in agricultural soils amended with fertilizer.
\end{abstract}

Keywords: Cement-dust pollution; Multivariate statistics; Nutrient dynamics, Enzyme activity fluxes; Microbial biomass; Corn yield

\section{INTRODUCTION}

Zea mays L or maize (corn) is a very popular crop plant that thrives excellently in the tropical and warm sub-tropical Africa, Latin America and Asia, where it is primarily used as human food and animal feed owing to its large carbohydrate content (Olaniyan and Lucas, 2004). On a global scale, corn ranks third among the cereals in terms of earnings upon investment (Akongwubel $\boldsymbol{e}$ al., 2012). On the African continent, Nigeria is only second to South Africa in production but placed eleventh in terms of corn yield (FAOSTAT, 2014).

Corn and/or its products have found wide applications in households and industries including food, dairy, brewery and distillery (Undie et al., 2012). In Southern Nigeria, corn is mostly consumed directly as snack, in boiled or roasted form, or processed into flour and consumed in a variety of forms (Akongwubel et al., 2012).

The dominant factors that influence corn yield have been identified as soil type, climate, soil health and fertility, corn variety and cropping method (Akongwubel et al., 2012; Undie et al., 2012). As a hardy plant, corn has the ability to grow on a vast array of soils, but best yield is reported in rich loamy or sandy-loamy soils under salutary climatic conditions (Undie et al., 2012). Nigeria has an abundance of these soil types with adequate health and fertility for high yield. However, $\mathrm{pH}$, soil organic carbon, phosphorus, nitrogen, micronutrients and soil moisture levels influence soil fertility owing to changes in their status arising, mostly, from anthropogenic pollution from industries (Zerrouqi et al., 2008; Gordon et al., 2013).

Generally, industries are categorized as high-polluting, less-polluting and nonpolluting by the ministries of environment and forest, on the basis of their capacities to pollute the environment. Cement industries are regarded as highpolluting, especially with regard to particulate emissions considering their role in pollution hazards and environmental imbalance. Their emissions pollute the environment in the form of dusts as they escape during factory processing (Kulandaivel et al., 2015).

Cement manufacturing releases alkaline particulate gaseous pollutants and other particles into the soil (Hemida, 2005; Bilen, 2010). Their direct effects have been reported to include ecosystem alkalination and undesirable soil physicochemical composition and biological activity (Nowak et al., 2003; Ocak et al., 2004). Documented reports show that cement dust trigger considerable $\mathrm{pH}$ changes arising from inputs of oxides like Cao, $\mathrm{Fe}_{2} \mathrm{O}_{3}, \mathrm{SiO}_{2}, \mathrm{Al}_{2} \mathrm{O}_{3}, \mathrm{MgO}, \mathrm{K}_{2} \mathrm{O}$, $\mathrm{Na}_{2} \mathrm{O}$ and $\mathrm{SO}_{3}$ and accumulation of toxic metals like hexavalent chromium, nickel, cadmium and lead (Saddique, 2014). Mediation of metal toxicity to soil microorganisms and their metabolism by $\mathrm{pH}$ occasioned on the availability of suitable ligands has been copiously documented (Ekpenyong and Antai, 2007a,b; Ekpenyong et al., 2007; Hagmann et al., 2015). The consequences are reductive changes in microbial quality content and their biochemical and/or physiological activities (McCarthy et al., 2003; Biyik et al., 2005). Microbial biomass and soil enzyme activities are therefore reliable soil fertility indices since their responses to variations in soil properties occasioned on pollutant presence are rapid and measureable (Bilen, 2010; Panettieri et al., 2013). Their composition and activities also adequately reflect biological and biogeochemical changes brought about by the pollution (Bayhan et al., 2002; Bacmaga et al., 2015).

In the ancient city of Calabar, Nigeria, where a cement factory is located near agricultural farmlands, surrounding soils have been reported to yield poorly, even after fertilizer application. This has sparked off youth restiveness in the area with frequent kidnap of Health and Tertiary Institution workers. The present study comparatively investigated the fertility status of farmlands surrounding the cement factory, pristine soils and polluted soils amended with fertilizer. Multivariate statistical tools, namely, correlation analysis (CA), principal component analysis (PCA), agglomerative hierarchical cluster analysis (AHCA) and multivariate analysis of co-variance (MANCOVA) were used. These approaches have earlier been reported as successful and therefore reliable in studies on fertility parameters of humic soil cultivated with coffee (Silva and Lima, 2012), trace metal contamination of sediments (Benson et al., 2016), soil fertility parameters around nuclear power plant (Shinde et al., 2016), determination of soil pedoenvironmental indicators (Oliveira et al., 2017) and soil fertility relationships for predicting environmental persistence of pollutants (Katseanes et al., 2017). 


\section{MATERIALS AND METHODS}

\section{Area of study}

Calabar soils are characteristically described as sandy-loamy (Ibanga $\boldsymbol{e t}$ al. 1989; Akpan-Idiok and Ogbaji, 2013). The area is a tropical rainforest (Akpan et al., 2017), with average rainfall almost all year round but with sufficient sunlight that makes corn planting possible three times per year; March to June (early-season), May to September (mid-season) and September to January (lateseason corn)(Undie et al., 2012). The study area was United Cement Company Plant located within Latitude $40^{\circ} 53^{\prime}$ and $50^{\circ} 05^{\prime} \mathrm{N}$ and Longitude $80^{\circ} 15^{\prime}$ to $80^{\circ} 27^{\prime} \mathrm{E}$ of Calabar, Cross River State, at the limestone belt of Mfamosing and surrounding fields in Akamkpa Local Government Area $(2 \mathrm{~km}$ east and west ends from the factory). Total area of study was $1 \mathrm{~km}^{2}$ including the factory. The southern end of the factory is bordered by the Akpayafe River while the northern end accommodates roads and residential areas, leaving the western and eastern borders for agricultural practices.

\section{Study design and sampling}

A total of 108 samples were collected from 3 types of soil over 3 planting periods; 36 samples per soil type. The cement-dust polluted area was divided into 24 acres ( $\left.24 \times 4046.86 \mathrm{~m}^{2}\right) ; 12$ acres (6 west and 6 east of factory) were tilled to a depth of $30 \mathrm{~cm}$, fertilized with 2 pounds of NPK/acre (16:16:8) and allowed to fallow for two weeks. This was used as polluted but treated soil (POT). The remaining 12 acres were left un-amended and described as polluted (POL) soil samples. The control soil (CON), located at the Cross River University of Technology research garden on $5^{\circ} 15^{\prime \prime} \mathrm{N} ; 8^{\circ} 22^{\prime \prime} \mathrm{E}$ at approximately 25 kilometers from the factory, was also divided into 12 acres. For each planting period, 4 replicate acres per soil type were sampled by means of a hand auger from the first $20 \mathrm{~cm}$ depth of the different soil types after removing vegetation. Three subsamples were collected from each acre diagonally positioned $500 \mathrm{~m}$ one from another into sterile wide-mouth sampling bottles. The bottles were properly labeled, placed in ice-packed coolers and transported to the laboratory within 1 hour of collection for preparation and analyses.

\section{Sample preparation}

Broken bottles, sticks, polyethylene substances and other unwanted materials were carefully separated from each of the 3 sub-samples and samples homogenized by means of a laboratory homogenizer (SAMRO-SRH50-80, China). The sub-samples were pooled to obtain 4 composite samples per acre per soil type per planting period. Required amount of samples were weighed, by means of a digital balance (METTLER-TOLEDO), from the composite sample for the various analyses that followed. For analyses that did not require much urgency, samples were preserved in the refrigerator at $4^{\circ} \mathrm{C}$ until required. Dilutions of soil samples were prepared for microbial analyses. All analyses were initiated within $16 \mathrm{~h}$ following collection of samples.

\section{Determination of soil microbial biomass-carbon}

To estimate the amount of carbon trapped in microbial biomass in soil samples, the method of fumigation and subsequent extraction with chloroform, reputed as standard method for microbial biomass determination (Vance et al., 1987; Bailey et al., 2002), was employed. Briefly, $5 \mathrm{~g}$ of each of chloroform-exposed and unexposed subsamples were transferred into $70 \mathrm{~mL}$ glass (Pyrex) tubes followed by addition of $40 \mathrm{~mL}$ potassium sulfate $\left(0.5 \mathrm{M} \mathrm{K}_{2} \mathrm{SO}_{4}\right)$ solution to each sample. Subsequently, $0.5 \mathrm{~mL}$ ethanol-free chloroform was added to one sub-sample and tubes covered with chloroform-resistant caps. The tubes were shaken at $150 \mathrm{rpm}$ for $4 \mathrm{~h}$ and then left for $10 \mathrm{~min}$. The top $30 \mathrm{~mL}$ of the soil extracts were decanted and filtered. The filtrate was collected in $50 \mathrm{~mL}$ centrifuge tubes and forcibly injected with air for $30 \mathrm{~min}$ (to rid extracts of chloroform) using long spinal tap needles. Potassium sulfate $\left(0.5 \mathrm{M} \mathrm{K}_{2} \mathrm{SO}_{4}\right)$ served as blank. The control and chloroform-exposed extracts were analyzed for total dissolved $\mathrm{C}$ using a persulfate digestion technique. Dissolved $\mathrm{C}$ concentration in the $\mathrm{K}_{2} \mathrm{SO}_{4}$ blanks (no soil added) with and without chloroform were subtracted from the extract concentrations of the chloroform-exposed and the control samples. Amount of biomass carbon extracted was determined as the difference in total dissolved carbon between the chloroform-treated sub-sample and its comparable control sub-sample.

Total Microbial Biomass C (extractable + non-extractable biomass) was determined using equation;

$$
\text { Total Microbial Biomass }(T M B)=2.68 \mathrm{~V}-44.1
$$
(Vance et al., 1987)

where $\mathrm{V}$ represents net flush of carbon from fumigated and un-fumigated $\mathrm{K}_{2} \mathrm{SO}_{4}$ ( $0.5 \mathrm{M}, \mathrm{pH}$ 7.0)-extracted soils. Results were expressed as microgram chloroform extractable biomass C/gram of dry soil.

\section{Enumeration of cultivable aerobic bacteria}

Three appropriate dilutions from each of a 10-fold serially-diluted sample were plated on tryptic soy agar in triplicates by the pour plating method. Plates were incubated for $36 \mathrm{~h}$ at $28 \pm 2^{\circ} \mathrm{C}$. Bacterial enumerations were performed by means of colony counter (Scan 1200 Colony counter, USA) (Ekpenyong et al., 2007b). Mean counts presented in standard forms were subsequently transformed to $\log _{10}$ values and used for analysis.

\section{Enumeration of cultivable fungi}

Total fungi comprising yeasts and molds were enumerated on Czapek-Dox agar (CDA) and triplicate plates incubated at $30^{\circ} \mathrm{C}$ for $48-72 \mathrm{~h}$. Discrete colonies of yeasts and molds were enumerated and expressed as described for bacteria Attention was paid to the ratio of yeasts to molds per plate and per sample.

\section{Determination of soil enzymatic activities}

Dehydrogenase activity evaluation followed the protocol of Casida et al. (1964) using soil amended with $\mathrm{CaCO}_{3}$. The activity was based on the conversion of 2 , 3, 5- triphenyltetrazolium chloride substrate to the reddish-colored waterinsoluble formazan products whose intensities were measured spectrophotometrically at $485 \mathrm{~nm}$ wavelength with methanol as blank. Results obtained were compared with triphenyl formazan standards.

Alkaline phosphatase activity was evaluated using acetate buffer at $\mathrm{pH} 9.0$ Reactions were stopped using a combination of $0.5 \mathrm{~mol} / \mathrm{L} \mathrm{CaCl} 2$ and $0.5 \mathrm{~mol} / \mathrm{L}$ $\mathrm{NaOH}$. For one hour, enzyme activity reactions were held in a water bath at $37^{\circ} \mathrm{C}$ and cleavage product identified at a wavelength of $410 \mathrm{~nm}$ (Alef et al., 1998).

$\beta$-glucosidase activity was evaluated by the adding $p$-nitrophenyl- $\beta$-Dglucopyranoside to $1 \mathrm{~g}$ of soil (Eivazi and Tabatabai, 1988). The reaction was stopped by the addition of $0.02 \mathrm{~mol} / \mathrm{L}$ Tris at $\mathrm{pH} 12.0$. The cleavage product, $p$ nitrophenol glucoside was detected and quantified using UV-Vis spectrophotometer (Perkin-Elmer Lambda 25, MA-USA) at $464 \mathrm{~nm}$ wavelength.

\section{Physicochemical analyses of samples}

Soil $\mathrm{pH}$ was determined by potentiometry using $1 \mathrm{M}$ aqueous solution of potassium chloride $(\mathrm{KCl})$. Total nitrogen $(\mathrm{TN})$ was determined as described by Janssen (2003). Available phosphorus (AvP) was determined by the colorimetric ascorbic acid method (Olsen, 1954; Ichikogu, 2012) while the procedure of wet oxidation was followed to estimate soil organic carbon (SOC), using chromic acid as oxidant (McLeod, 1973).

\section{Validation experiment for determination of corn-crop yield}

Maize (Zea mays L.), otherwise called corn, was planted on 12 acres $(12 \times$ $4046.86 \mathrm{~m}^{2}$ ) per planting period on each of polluted soil (POL), treated-polluted soil (POT) and the control soil $(\mathrm{CON})$. Each cultivated acre contained 40 ridges (rows) and each ridge had 500 corn stands. A ridge was separated from the next by a distance of $85 \mathrm{~cm}$ while corn stands were separated one from another by a distance of $25 \mathrm{~cm}$. Seeds were planted during the 3 planting periods of October (1), March (2) and July (3), and were harvested 3 months later. Corn yields, expressed as bushels/acre, were determined using the equation below and compared among the three types of soil using one-way analysis of covariance (ANCOVA).

Yield (bushels acre $\left.{ }^{-1}\right)=$ kernels ear $^{-1} \times \frac{\text { ears acre }^{-1}}{\text { kernels bushel }^{-1}}$

Eqn. 2

\section{Statistical analyses}

Data was first subjected to Pearson bivariate correlation to establish data appropriateness for multivariate statistics. Over-correlated data were removed and principal component analysis (PCA) performed on remaining data. Results from PCA were confirmed by a dendrogram obtained by Euclidean distance of Ward linkage method of an agglomerative hierarchical cluster analysis (AHCA). Impact of cement-dust on selected outcome variables was evaluated by multivariate and univariate analyses of covariance (one-way MANCOVA and one-way ANCOVA respectively) of corn yield data. SPSS version 20.0 (IBM, USA) was employed to conduct all the statistical analyses.

\section{RESULTS}

\section{Pearson bivariate correlations of dependent variables}

Results of bivariate correlations computed to determine the appropriateness or otherwise of multivariate statistics of data are presented in Table 1. The results showed that soil organic carbon (SOC) had high significant correlation $(p<.01)$ with all other 8 dependent variables except a moderately significant negative correlation $(r=-.332 ; p=.048<.05)$ with $\beta$-glucosidase activity (BGA). Total 
nitrogen (TN) had high significant correlations with other test variables except that its correlations with available phosphorus (AvP: $r=.353, p=.034<.05$ ) and BGA $(r=-.332, p=.023<.05)$ were moderate. The weak negative correlation of available phosphorus (AvP) with BGA was not significant $(r=-.310, p=.066>$ $.05)$; however, the variable had moderate correlations $(p<.05)$ with total nitrogen $(\mathrm{TN})$ and fungal count (LOG10FC) but its relationship with the remaining variables were significantly high $(p<.01)$.

Results also showed weak relationships of dehydrogenase activity (DHA) with alkaline phosphatase activity (ALPA: $r=.227, p=.101>.05$ ) and $\beta$-glucosidase activity (BGA: $r=.328, p=.051>.050$ ). Alkaline phosphatase activity (ALPA) and $\beta$-glucosidase activity (BGA), in turn, showed respectively, weak correlation with fungal count; LOG10FC: $r=-.328, p=.051>.050$ and $r=-.248, p=.144>$ .050. Cultivable aerobic bacterial population (LOG10BC) strongly correlated with LOG10FC and total soil microbial biomass-carbon (SMB-C), however, the relationship with LOG10FC was negative while that with SMB-C was positive.

\section{Principal component analysis (PCA) of interrelationships among soil fertility parameters}

Another test of appropriateness of PCA was based on test results of sampling adequacy using Kaiser-Meyer-Olkin (KMO) as well as that of sphericity using Bartlett's test. A KMO of .60 and above with a significant $(p<.05)$ sphericity test result suggest that data was adequate to conduct a PCA. Our results revealed a KMO of .765 and a significant $(p<.0005)$ sphericity test suggesting that the assumption of an identity matrix in the data should be rejected and a PCA accordingly performed to determine the interrelationships between and among fertility parameters in the various soils studied.

The "Total Variance Explained" table of the PCA is presented in Table 2 to show the importance of each of the 9 principal components. The table revealed that only two components had initial eigenvalues $\geq 1.0$ suggesting that the PCA constructed two principal components from the survey items. The table showed a cumulative explained variance of $68.33 \%$ with principal component 1 (PC1) contributing $57.12 \%$ and PC2 only $11.21 \%$. The number of extracted components is also presented as a Scree plot in Figure 1 to show the elbow (break) point of the plot indicating two extracted principal components

The two components were subjected to matrix rotation using Varimax with Kaiser Normalization. The resultant rotated matrix revealed that LOG10BC ( $r=$ $.766)$, SMB-C $(r=.754)$ and ALPA $(r=.923)$ all had high positive loadings on PC1 and respectively low negative loadings $(r=.355),(r=-.344),(r=-.107)$ on PC2. Fungal count (LOG10FC) had a high positive loading $(r=.863)$ on PC2 but low negative loading $(r=-.185)$ on PC1 while DHA had a high negative loading $(r=-.830)$ on PC2 but a low positive one $(r=.230)$ on PC1. The factor loadings in rotated space are presented as Figure 2 . The angles of rotation were determined by treating the correlation coefficients, $r$ of the two principal components as cosines of angles. Since the correlation coefficient for PC1 was .824 , the angle of rotation was $34.51^{\circ}$ and that for PC2 $(r=.566)$ was $55.53^{\circ}$.

\section{Cluster analysis of soil fertility parameters}

The results of principal component analysis (PCA) were confirmed with hierarchical cluster analysis (HCA) using Euclidean distance of a Ward linkage of an agglomerative schedule. The proximity matrix, just like the correlation matrix in principal component analysis (PCA) showed that Euclidean distance between soil organic carbon and total nitrogen (SOC-TN), soil organic carbon and available phosphorus (SOC-AvP), soil organic carbon and fungal count (SOC-LOG10FC) were respectively 4.549, 4.460 and 5.991. These results, presented as a dendrogram in Figure 3, therefore revealed two hierarchical clusters of variables. Cluster 1 comprised SOC, TN, AvP and LOG10FC with low (4.00 - 6.00) Euclidean distance between any pair. Cluster 2 consisted of alkaline phosphatase activity (ALPA), $\beta$-glucosidase activity (BGA), dehydrogenase activity (DHA), bacterial population (LOG10BC) and soil microbial biomass-carbon (SMB-C) with high Euclidean distance between any pair $(6.00-12.00)$.

Table 1 Pearson bivariate correlations of dependent variables

\begin{tabular}{|c|c|c|c|c|c|c|c|c|c|c|}
\hline & & SOC & TN & AvP & DHA & ALPA & BGA & LOG10 BC & LOG10 FC & SMB-C \\
\hline SOC & $\begin{array}{l}\text { Correlation } \\
\text { Sig. }\end{array}$ & 1 & & & & & & 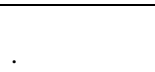 & & \\
\hline $\mathrm{TN}$ & $\begin{array}{l}\text { Correlation } \\
\text { Sig. }\end{array}$ & $\begin{array}{l}.704^{* *} \\
.000\end{array}$ & 1 & & & & & & & \\
\hline AvP & $\begin{array}{l}\text { Correlation } \\
\text { Sig. }\end{array}$ & $\begin{array}{l}.716^{* *} \\
.000\end{array}$ & $\begin{array}{l}.353^{*} \\
.034\end{array}$ & 1 & & & & & . & \\
\hline DHA & $\begin{array}{l}\text { Correlation } \\
\text { Sig. }\end{array}$ & $\begin{array}{l}-.517^{* *} \\
.001\end{array}$ & $\begin{array}{l}-.500^{* *} \\
.002\end{array}$ & $\begin{array}{l}-.486^{* *} \\
.003\end{array}$ & 1 & & & & & \\
\hline ALPA & $\begin{array}{l}\text { Correlation } \\
\text { Sig. }\end{array}$ & $\begin{array}{l}-.733^{* *} \\
.000\end{array}$ & $\begin{array}{l}-.596^{\text {** }} \\
.000\end{array}$ & $\begin{array}{l}-.685^{* *} \\
.000\end{array}$ & $\begin{array}{l}.277 \\
.101\end{array}$ & 1 & & & & \\
\hline BGA & $\begin{array}{l}\text { Correlation } \\
\text { Sig. }\end{array}$ & $\begin{array}{l}-.332^{*} \\
.048\end{array}$ & $\begin{array}{l}-.378^{*} \\
.023\end{array}$ & $\begin{array}{l}-.310 \\
.066\end{array}$ & $\begin{array}{l}.328 \\
.051\end{array}$ & $\begin{array}{l}.486^{* *} \\
.003\end{array}$ & 1 & & & \\
\hline LOG10 BC & $\begin{array}{l}\text { Correlation } \\
\text { Sig. }\end{array}$ & $\begin{array}{l}-.589^{* *} \\
.000\end{array}$ & $\begin{array}{l}-.665^{* *} \\
.000\end{array}$ & $\begin{array}{l}-.569^{* *} \\
.000\end{array}$ & $\begin{array}{l}.440^{* *} \\
.007\end{array}$ & $\begin{array}{l}.691^{* *} \\
.000\end{array}$ & $\begin{array}{l}.436^{* *} \\
.008\end{array}$ & 1 & & \\
\hline LOG10 FC & $\begin{array}{l}\text { Correlation } \\
\text { Sig. }\end{array}$ & $\begin{array}{l}.487^{* *} \\
.003\end{array}$ & $\begin{array}{l}.573^{* *} \\
.000\end{array}$ & $\begin{array}{l}.377^{*} \\
.023\end{array}$ & $\begin{array}{l}-.584^{* *} \\
.000\end{array}$ & $\begin{array}{l}-.328 \\
.051\end{array}$ & $\begin{array}{l}-.248 \\
.144\end{array}$ & $\begin{array}{l}-.461^{* *} \\
.005\end{array}$ & 1 & \\
\hline SMB-C & $\begin{array}{l}\text { Correlation } \\
\text { Sig. }\end{array}$ & $\begin{array}{l}-.546^{* *} \\
.001\end{array}$ & $\begin{array}{l}-.748^{* * *} \\
.000\end{array}$ & $\begin{array}{l}-.528^{* *} \\
.001\end{array}$ & $\begin{array}{l}.450^{* * *} \\
.006\end{array}$ & $\begin{array}{l}.663^{* *} \\
.000\end{array}$ & $\begin{array}{l}.403^{*} \\
.015\end{array}$ & $\begin{array}{l}.714^{* * *} \\
.000\end{array}$ & $\begin{array}{l}-.385^{*} \\
.020\end{array}$ & 1 \\
\hline
\end{tabular}

Legend: ** Significance level, $p=0.01$, $*$ Significance level, $p=0.05$, SOC-Soil organic carbon, TN-Total nitrogen, AvP-Available phosphorus, DHA-Dehydrogenase activity, ALPA-Alkaline phosphatase activity, BGA- $\beta$-glucosidase activity, LOG10BC-LOG 10 Bacterial count, LOG10FC-LOG 10 Fungal count, SMB-C-Soil microbial biomass-carbon

Table 2 Total explainable variance of a principal component analysis showing two extracted components

\begin{tabular}{|c|c|c|c|c|c|c|c|c|c|}
\hline \multirow[t]{2}{*}{ Component } & \multicolumn{3}{|c|}{ Initial Eigenvalues } & \multicolumn{3}{|c|}{ Extraction Sums of Squared Loadings } & \multicolumn{3}{|c|}{ Rotation Sums of Squared Loadings } \\
\hline & Total & $\%$ of Variance & Cumulative $\%$ & Total & $\%$ of Variance & Cumulative \% & Total & $\%$ of Variance & Cumulative $\%$ \\
\hline 1 & 5.141 & 57.117 & 57.117 & 5.141 & 57.117 & 57.117 & 3.817 & 42.408 & 42.408 \\
\hline 2 & 1.009 & 11.214 & 68.331 & 1.009 & 11.214 & 68.331 & 2.333 & 25.923 & 68.331 \\
\hline 3 & .794 & 8.826 & 77.156 & & & & & & \\
\hline 4 & .706 & 7.846 & 85.002 & & & & & & \\
\hline 5 & .465 & 5.164 & 90.166 & & & & & & \\
\hline 6 & .397 & 4.412 & 94.578 & & & & & & \\
\hline 7 & .261 & 2.897 & 97.475 & & & & & & \\
\hline 8 & .155 & 1.719 & 99.195 & & & & & & \\
\hline 9 & .072 & .805 & 100.000 & & & & & & \\
\hline
\end{tabular}

Extraction Method: Principal Component Analysis. 


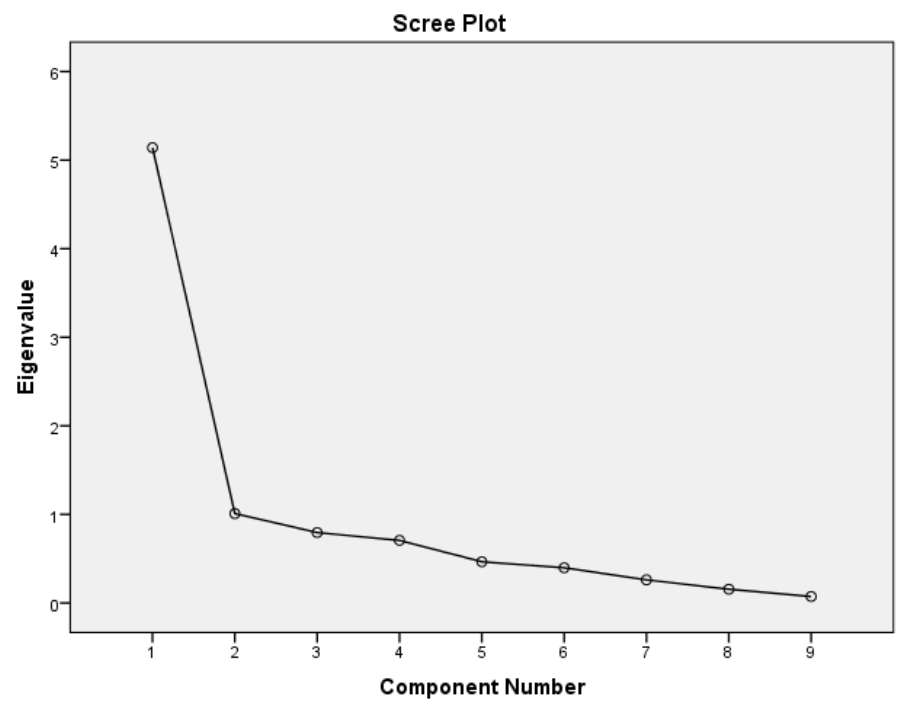

Figure 1 Scree plot of Eigenvalues against component number showing the elbow point for two principal components

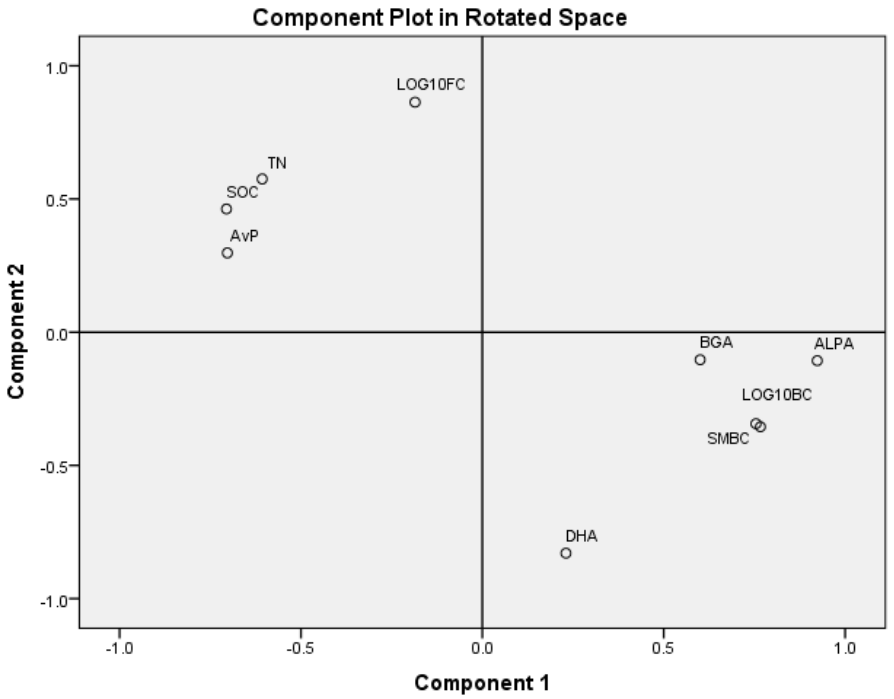

Figure 2 Extracted principal components of dependent variables in rotated space

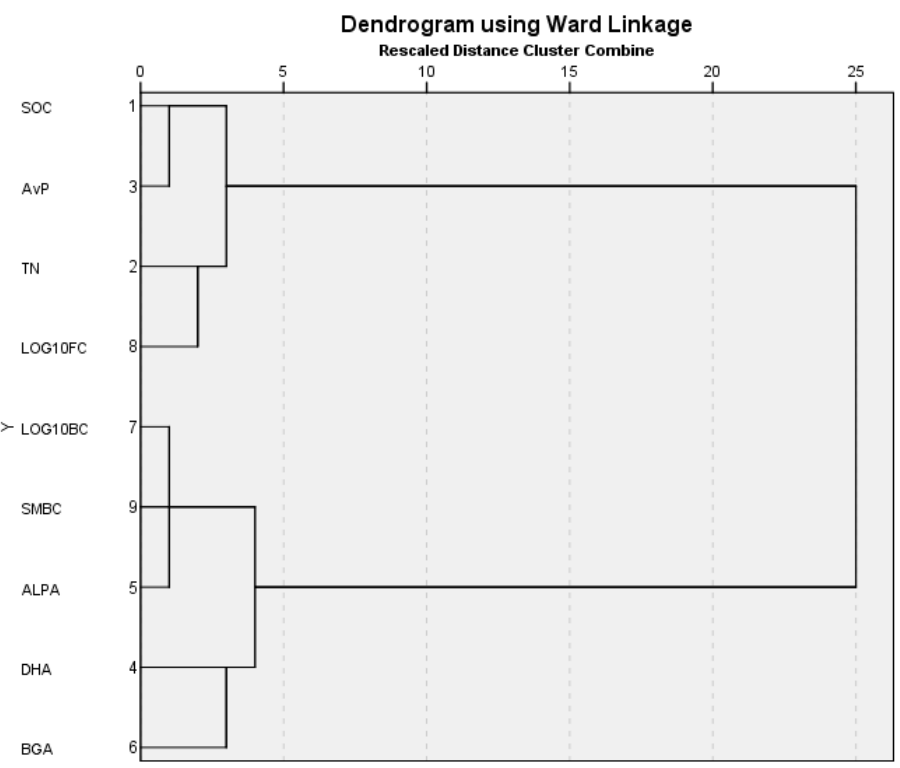

Figure 3 Dendrogram of a Ward linkage of an agglomeration schedule of a hierarchical cluster analysis (HCA) showing two variable clusters
Multivariate analysis of effect of soil type and planting period on fertility variables

Multivariate analysis of covariance (one-way MANCOVA) was adopted to ascertain the main effect of soil type on the nine moderately correlated dependent variables (DVs) when controlling for planting period as covariate. The homogeneity assumption given by the Box's test was significant, $F=1.692, p<$ .0005 , indicating violation of the assumption. However, the assumption of homogeneity test for equality of error variance was met (Table 3 ) by the nonsignificant $(p>.05)$ Levene's test for all 9 DVs.

Table 4 presents the four different multivariate tests conducted to explain the effect of soil type on the response variables when controlling for the effect of the covariate (planting period). The table showed that all four multivariate tests for the covariate were significant $(p<.0005)$. Because the Box M test of homogeneity assumption was violated, we reported the result from the very robust Pillai's Trace test. The results showed a statistically significant effect of the covariate on the DVs in combination: planting period, $F(9,24)=48.36, p<$ .0005 ; Pillai's Trace $=.948$, partial $\eta^{2}=.948$ and a statistically significant main effect of the categorical predictor variable on the DVs in combination when controlling for the covariate: soil type, $F(18,50)=31.12, p<.0005$; Pillai's Trace $=1.84$, partial $\eta^{2}=.918$

An extract of the tests of between-subjects effect (Table 5) results revealed that the covariate effects were not significant $(p>.05)$ for available phosphorus (Avp), dehydrogenase activity (DHA), $\beta$-glucosidase activity (BGA) and funga count (LOG10FC). However, for soil organic carbon (SOC), total nitrogen (TN), alkaline phosphatase activity (ALPA), bacterial count (LOG10BC) and soil microbial biomass-carbon (SMB-C), there were significant main effects among the independent levels for the covariate. Furthermore, Bonferoni's post hoc test was employed to separate significant means. The test revealed that significant difference in mean SOC levels existed between control soil (CON) and untreated polluted soil (POL) as well as between NKP-treated polluted soil (POT) and POL but not between CON and POT $(p=.448>.05)$ as can be seen in Figure $4 \mathrm{a}$ Mean total nitrogen (TN) was only significantly different between CON and POL $(p=.02<.05)$. The mean difference in TN between CON and POT $(p=.761>$ $.05)$ and POT and POL $(p=.276>.05)$ was not statistically significant (Figure 4b). Mean alkaline phosphatase activity (ALPA) was significantly different between all soil type pairs (Figure 5a). Bonferroni multiple comparison result also showed that mean bacterial population (LOG10BC) (Figure 6b) differed significantly between CON and POL and between CON and POT but not between POT and POL. There was significant nean difference in soil microbial biomass-carbon (SMB-C) between CON and POL $(p=.011<.05)$ (Figure 6a). However, no significant difference existed between CON and POT ( $p=.062>$ $.05)$ or between POT and POL $(p=1.000>.05)$.

The tests of between-subjects effect for the main effect revealed that only dehydrogenase activity (DHA) (Figure 5c) and fungal count (LOG10FC) (Figure 6c) were not significantly affected $(p>.05)$ by soil type. Bonferroni multiple comparisons showed non-significant mean difference in available phosphorus $(\mathrm{AvP})$ between $\mathrm{CON}$ and POT but significant mean difference existed between POT and POL and between CON and POL (Figure 4c). Mean $\beta$-glucosidase activity (BGA) (Figure 5b) differed significantly between CON and POL and between CON and POT but not between POT and POL $(p>.05)$.

\section{Evaluation of cement dust pollution effect on corn yield}

Analysis of covariance (one-way ANCOVA) was used to analyze corn yield data in cement dust polluted (POL), NPK-amended (POT) and control (CON) agricultural soils. Homogeneity assumption of the model was met by nonsignificant Levene's test result. The ANCOVA result, presented as Table 6 revealed that corn yield did not differ significantly with the covariate (planting period) but with soil type, $F(2,32)=21.54, p<.0005$; model adjusted $r^{2}=.534$ The control soil (CON) had a mean corn yield of 7.89 bushels/acre which was higher than those from NPK-amended polluted soil (POT-5.04 bushels/acre) and the un-amended polluted soil (POL-3.50 bushels/acre) as illustrated in Figure 7. Bonferroni multiple comparisons showed that mean difference in corn yield between CON and POL soils as well as that between CON and POT soils were significant. However, mean difference between POT and POL was not statistically significant $(p=.089>.05)$. We calculated loss in corn yield in relation to control soil using the equation: Yield loss $(\%)=Y_{\text {con }}-\frac{Y_{x}}{Y_{c o n}} \times$ 100

Eqn. 3

where $Y_{\text {con }}$ is corn yield in control soil (CON) and $Y_{x}$ is corn yield from NPK treated polluted soil (POT) or un-amended cement dust polluted soil (POL) Relative to control soil, per cent loss in corn yield was $55.69 \%$ in un-amended cement dust-polluted soil and $36.07 \%$ in NPK-treated polluted soil.

\section{DISCUSSION}

Soil fertility parameters are all interrelated and interact with the biologica component of the soil in diverse ways. Multivariate statistics; a robust statistical tool with potential to identify, classify, quantify and interpret these relationships; was employed in this study. Multivariate statistics are used to account for 
confounding effects, account for more variance in an outcome, and predict for outcomes. There are different multivariate approaches in frequent use (Benson $\boldsymbol{e t}$ al., 2016). These include correlation analysis; Principal component analysis or factor analysis, agglomerative hierarchical cluster analysis (Francl, 1993; Jia $\boldsymbol{e}$ al., 2010; Benson et al., 2016) and multivariate analysis of variance or covariance (Samec et al., 2007). The present study employed the techniques of correlation analysis (CA), principal component analysis (PCA), agglomerative hierarchical cluster analysis (AHCA) and multivariate analysis of covariance (MANCOVA) to investigate the impact of cement dust pollution on nine fertility parameters of an agricultural soil and the consequence of that impact on crop yield.

Soil fertility studies suggest a large number of parameters to indicate soil health and fertility, particularly for agricultural purposes (Dawes and Goonetilleke, 2006; Samec et al., 2007; Shinde et al., 2016). Our study originally evaluated 12 fertility parameters including soil organic carbon (SOC), total nitrogen (TN), available phosphorus (AvP), $\mathrm{pH}(\mathrm{pH})$, soil moisture content (SMC), dehydrogenase activity (DHA), acid phosphatase activity (ACPA), alkaline phosphatase activity (ALPA), $\beta$-glucosidase activity (BGA), bacterial count (LOG10BC), fungal count (LOG10FC) and soil microbial biomass-carbon (SMB-C). However, Pearson bivariate correlation removed $\mathrm{pH}, \mathrm{SMC}$ and ACPA on the basis of violation of the multicolinearity assumption for a multivariate analysis. It is important to comment here that, although multivariate statistics simulates real life situations, its nine assumptions are often not met in real life Attempts at meeting multivariate statistics assumptions, often attained by removal of 'over-correlated' variables, frequently result in loss of very useful information (Juhos et al., 2015). In this study, pH, SMC and ACPA were removed before PCA, AHCA and MANCOVA were conducted.

The high significant but moderate inter-correlation among SOC, TN and AvP was not surprising because these nutrient elements are the major building blocks of cellular organisms including plants and microorganisms. Carbon is required for the synthesis of the carbon skeleton of all life forms while nitrogen remains a major limiting nutrient for several life processes and/or functions. The synthesis of the genetic material (DNA) and energy currency of cellular organisms, ATP, leans heavily on the availability of phosphorus in the environment without which biochemical reactions will not occur (Ekpenyong et al., 2017a). Availability of these nutrients in adequate amounts is the major driver of numerous soil biological activities required to establish and sustain soil fertility. Fertility limits/ranges of these elements for agricultural practices are detailed in Landon (1991) and FDALR (1990).

Table 3 Levene's test for homogeneity assumption

\begin{tabular}{lllll}
\hline & F & df1 & df2 & Sig. \\
\hline Soil organic carbon & 1.859 & 2 & 33 & .172 \\
Total nitrogen & 1.953 & 2 & 33 & .158 \\
Available phosphorus & .820 & 2 & 33 & .449 \\
Dehydrogenase activity & .576 & 2 & 33 & .567 \\
Alkaline phosphatase activity & 1.492 & 2 & 33 & .240 \\
及-glucosidase activity & .194 & 2 & 33 & .825 \\
LOG10 Bacterial count & .346 & 2 & 33 & .710 \\
LOG10 Fungal count & 1.302 & 2 & 33 & .286 \\
Soil microbial biomass-carbon & .291 & 2 & 33 & .749 \\
\hline
\end{tabular}

Significance level, $p=.05$

Table 4 Multivariate tests results of a one-way multivariate analysis of covariance (MANCOVA)

\begin{tabular}{|c|c|c|c|c|c|c|c|c|c|}
\hline Effect & & Value & $\mathbf{F}$ & Hypothesis df & Error df & Sig. & $\begin{array}{l}\text { Partial Eta } \\
\text { Squared }\end{array}$ & $\begin{array}{l}\text { Noncent. } \\
\text { Parameter }\end{array}$ & Observed Power \\
\hline \multirow[t]{4}{*}{ Intercept } & Pillai's Trace & .990 & 253.153 & 9.000 & 24.000 & .000 & .990 & 2278.379 & 1.000 \\
\hline & Wilks' Lambda & .010 & 253.153 & 9.000 & 24.000 & .000 & .990 & 2278.379 & 1.000 \\
\hline & Hotelling's Trace & 94.932 & 253.153 & 9.000 & 24.000 & .000 & .990 & 2278.379 & 1.000 \\
\hline & Roy's Largest Root & 94.932 & 253.153 & 9.000 & 24.000 & .000 & .990 & 2278.379 & 1.000 \\
\hline \multirow[t]{4}{*}{ Period } & Pillai's Trace & .948 & 48.357 & 9.000 & 24.000 & .000 & .948 & 435.213 & 1.000 \\
\hline & Wilks' Lambda & .052 & 48.357 & 9.000 & 24.000 & .000 & .948 & 435.213 & 1.000 \\
\hline & Hotelling's Trace & 18.134 & 48.357 & 9.000 & 24.000 & .000 & .948 & 435.213 & 1.000 \\
\hline & Roy's Largest Root & 18.134 & 48.357 & 9.000 & 24.000 & .000 & .948 & 435.213 & 1.000 \\
\hline \multirow[t]{4}{*}{ Soiltype } & Pillai's Trace & 1.836 & 31.122 & 18.000 & 50.000 & .000 & .918 & 560.195 & 1.000 \\
\hline & Wilks' Lambda & .006 & 32.133 & 18.000 & 48.000 & .000 & .923 & 578.398 & 1.000 \\
\hline & Hotelling's Trace & 25.909 & 33.106 & 18.000 & 46.000 & .000 & .928 & 595.916 & 1.000 \\
\hline & Roy's Largest Root & 17.898 & 49.715 & 9.000 & 25.000 & .000 & .947 & 447.439 & 1.000 \\
\hline
\end{tabular}

Table 5 Extract of Tests of between-subjects effects of MANCOVA showing only covariate and the categorical variable

\begin{tabular}{|c|c|c|c|c|c|c|c|c|c|}
\hline Source & & $\begin{array}{l}\text { Type III Sum } \\
\text { of Squares }\end{array}$ & df & $\begin{array}{l}\text { Mean } \\
\text { Square }\end{array}$ & $\mathbf{F}$ & Sig. & $\begin{array}{l}\text { Partial Eta } \\
\text { Squared }\end{array}$ & $\begin{array}{l}\text { Noncent. } \\
\text { Parameter }\end{array}$ & $\begin{array}{l}\text { Observed } \\
\text { Power }\end{array}$ \\
\hline \multirow{5}{*}{ Period } & $\mathrm{TN}$ & .446 & 1 & .446 & 64.055 & .000 & .667 & 64.055 & 1.000 \\
\hline & DHA & 107.823 & 1 & 107.823 & 3.783 & .061 & .106 & 3.783 & .471 \\
\hline & ALPA & 67.402 & 1 & 67.402 & 28.624 & .000 & .472 & 28.624 & .999 \\
\hline & BGA & .290 & 1 & .290 & .010 & .920 & .000 & .010 & .051 \\
\hline & SMB-C & 394632.954 & 1 & 394632.954 & 98.578 & .000 & .755 & 98.578 & 1.000 \\
\hline Soil & SOC & 203.300 & 2 & 101.650 & 63.464 & .000 & .799 & 126.928 & 1.000 \\
\hline \multirow[t]{5}{*}{ type } & $\mathrm{TN}$ & .172 & 2 & .086 & 12.381 & .000 & .436 & 24.763 & .993 \\
\hline & AvP & 200.356 & 2 & 100.178 & 19.345 & .000 & .547 & 38.690 & 1.000 \\
\hline & DHA & 92.454 & 2 & 46.227 & 1.622 & .213 & .092 & 3.243 & .317 \\
\hline & LOG10FC & 4.246 & 2 & 2.123 & 1.469 & .245 & .084 & 2.937 & .290 \\
\hline & SMB-C & 170761.907 & 2 & 85380.954 & 21.328 & .000 & .571 & 42.656 & 1.000 \\
\hline
\end{tabular}

Legend: SOC-Soil organic carbon; TN-Total nitrogen; AvP-Available phosphorus; DHA-Dehydrogenase activity; ALPA-Alkaline phosphatase activity; BGA- $\beta$-glucosidase activity; LOG10BC-LOG 10 Bacterial count; LOG10FC-LOG 10 Fungal count; SMB-C-Soil microbial biomass-carbon 

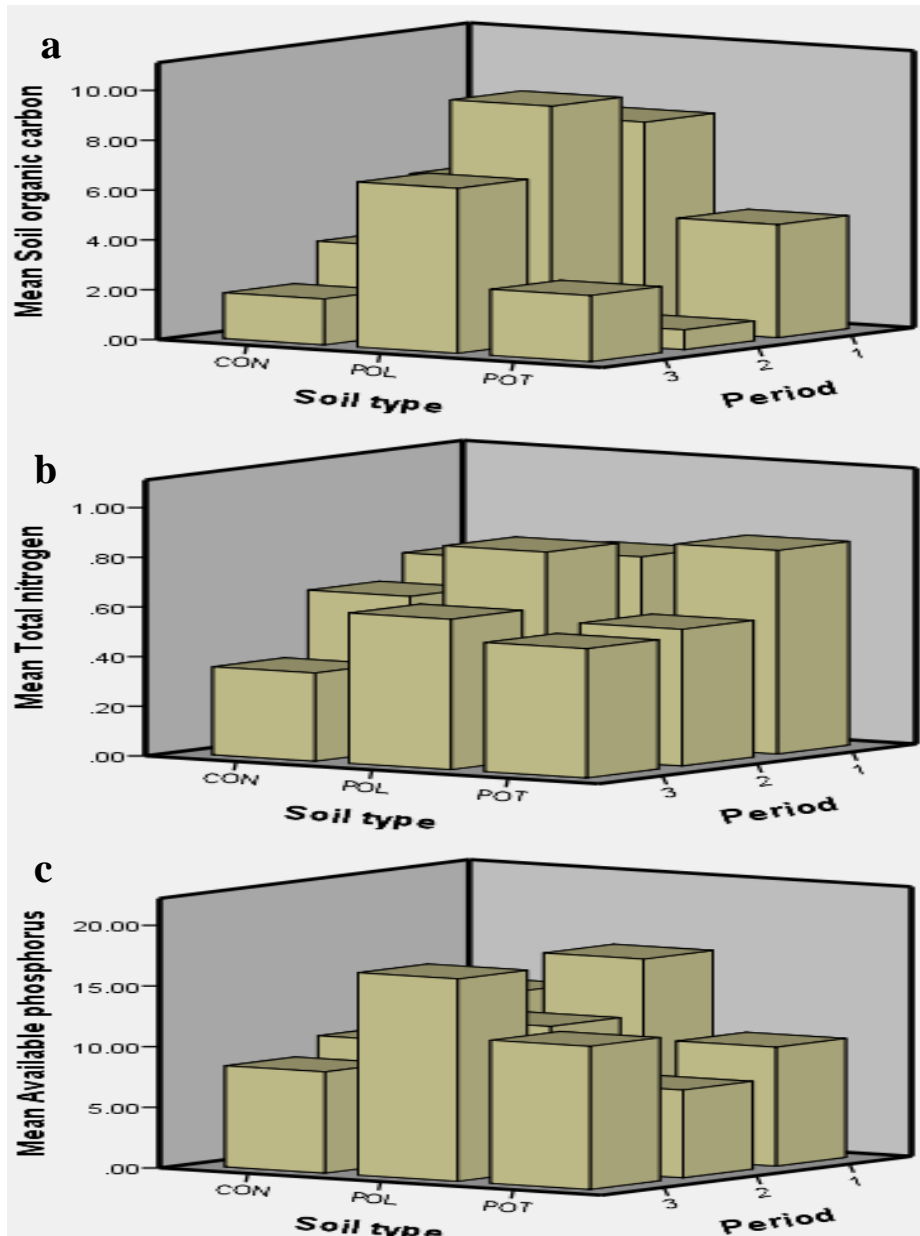

Figure 4 3-D bar representation of nutrient parameter fluxes in studied soils. aSoil organic carbon; b-Total nitrogen; c-Available phosphorus
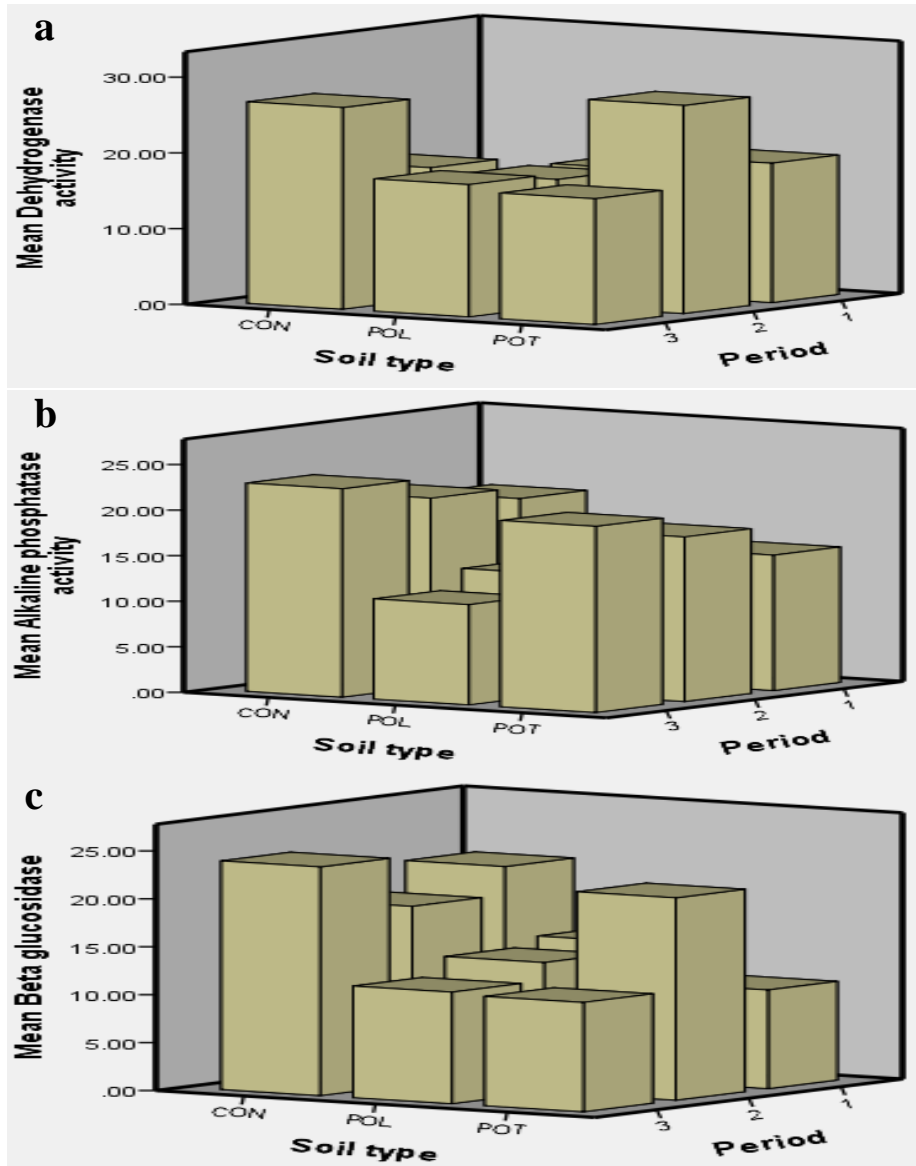

Figure 5 3-D bar representation of enzyme activity fluxes in studied soils. aDehydrogenase activity; b- Alkaline phosphatase activity; $\mathbf{c}-\beta$ glucosidase activity
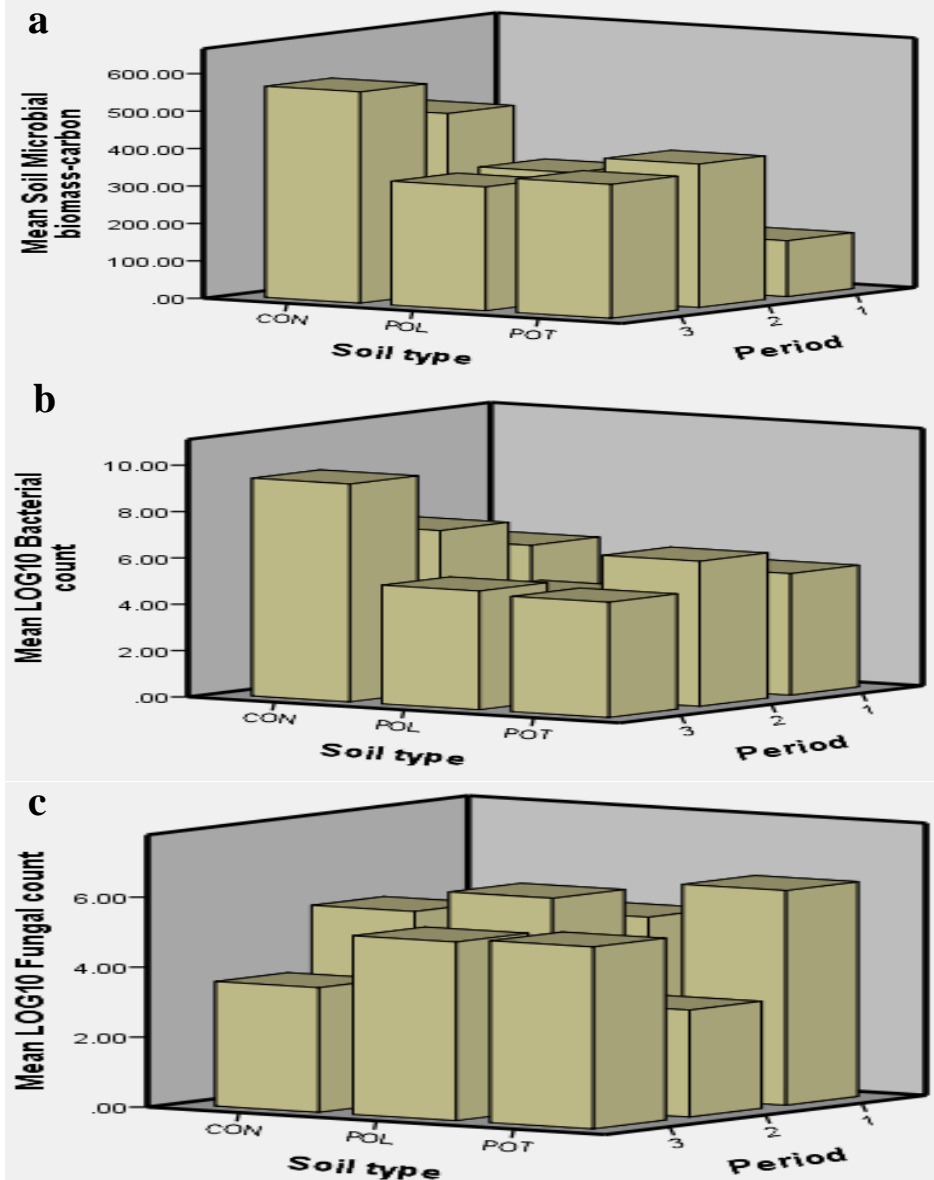

Figure 6 3-D bar representation of microbial biota fluxes in soils: a- Soil microbial biomass-carbon; b- LOG 10 Bacterial count; c- LOG 10 Fungal count

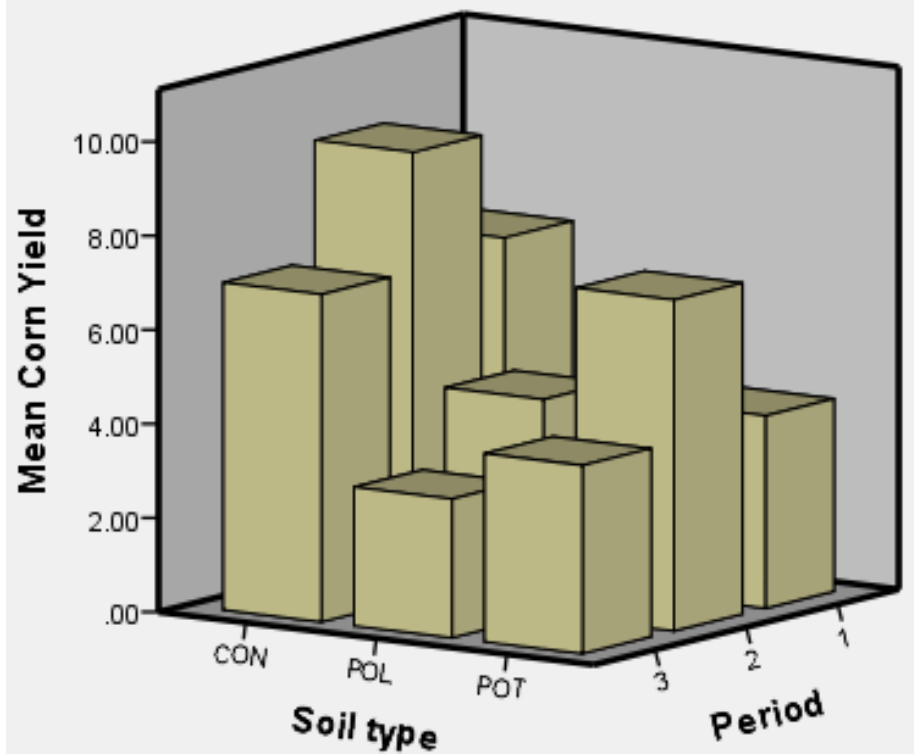

Figure 7 3-D bar representation of mean corn yield from studied soils at different planting period

Results from this study showed that these three elements correlated positively and significantly with each other. A fourth parameter with which they shared positive correlation was fungal population (LOG10FC). Understandably, the nutrient elements showed negative significant correlation with soil microbial biomass-C (SMB-C). This indicates that when soil microbial biomass-carbon increases in the soil, the organic carbon content (non-microbial) decreases owing to increased metabolism and conversion to microbial biomass carbon (Kaur $\boldsymbol{e}$ al., 2000). This study showed that fungal count, which forms a part of the 
microbial community, does not share the negative correlation with nutrient elements, but bacterial count (LOG10BC) does. We hypothesize that bacteria with their high specific growth rate outcompetes fungi in the presence of high organic carbon, thereby constituting the bulk of SMB-C, hence their significant positive correlation. Therefore as LOG10BC rises along with SMB-C, soil concentrations of LOG10FC, SOC, TN and AvP decrease. Spore-forming bacteria, particularly from Bacillus, and molds of the genera Aspergillus, Penicillium and Cladosporium, dominated the first surface layer of cement dust polluted soils but their populations were grossly reduced in control soil (CON) but less so in NPK-treated soils (POT) which were overtaken by yeast genera and more diverse bacterial species and genera.

Table 6 Tests of between-subjects effects of ANCOVA for corn yield data

\begin{tabular}{lllllllll}
\hline & \multicolumn{2}{l}{ Type III Sum of } & & & & & & \\
Source & Squares & df & Mean Square & F & Sig. & Partial Eta Squared & Noncent. Parameter & Observed Power \\
\hline Corrected Model & 119.302 & 3 & 39.767 & 14.368 & .000 & .574 & 43.104 & 1.000 \\
Intercept & 160.593 & 1 & 160.593 & 58.022 & .000 & .645 & 58.022 & 1.000 \\
Period & .074 & 1 & .074 & .027 & .871 & .001 & .027 & .053 \\
Soil type & 119.228 & 2 & 59.614 & 21.538 & .000 & .574 & 43.077 & 1.000 \\
Error & 88.569 & 32 & 2.768 & & & & & \\
Total & 1287.869 & 36 & & & & & & \\
Corrected Total & 207.871 & 35 & & & & & & \\
\hline
\end{tabular}

Pearson bivariate correlation also showed that dehydrogenase activity (DHA), alkaline phosphatase (ALPA) and $\beta$-glucosidase had negative correlations with the nutrient elements but positive correlation with SMB-C and bacterial count. It has been reported that microbial biomass represents very little source of nutrients relative to soil organic matter and standing tree biomass, however, it remains a repository of plant nutrients and a channel for soil organic matter incorporation (Templera et al., 2003). Biological oxidations of soil organic compounds are mostly, if not entirely, dehydrogenase-mediated reactions (Wolinska and Stepniewska, 2012). Since DHA measures microbial respiration, it very readily serves as a reliable index of soil respiration which correlates strongly and positively with SMB-C (Salazar et al., 2011). $\beta$-glucosidase is an important soi enzyme because of its involvement in the final steps of biodegradation of the most abundant carbon substrate, cellulose, in the soil (Vinhal-Freitas $\boldsymbol{e t}$ al., 2010; Adetunji et al., 2017). Its activity (BGA) is therefore significant in carbon cycling and hence an important indicator of biological activity and soil fertility (Stege et al., 2010). Alkaline phosphatase is essential in phosphate metabolism and is a useful index for determining agricultural soil quality (Nalini $\boldsymbol{e t}$ al., 2014). As soil microbial biomass increased, the activities of these three enzymes increased. Another poorly understood relationship was the negative correlation between AvP and ALPA. It was expected that an increase in alkaline phosphatase with increased bacterial population will lead to increased available phosphorus but the reverse was the case. This suggests that other parameters; especially trace metals (Ekpenyong et al., 2017b) or micronutrients (Fernandez-Moya et al. 2014) might be involved in the adjustment of the relationship between this enzyme and other parameters because relationships in natural environments are hardly ever bivariate.

Principal component analysis (PCA) is a dimension-reduction analytical process that involves the transformation of a large number of weakly to moderately correlated variables into a smaller number of uncorrelated variables. A correlation matrix that shows only a few correlations above .30 suggests discontinuation of the analysis (Tabachnick and Fidell, 1996). Our correlation analysis results showed that all but one of the correlations was above .30 suggesting that PCA could be conducted on the data. Our results revealed a KMO of .765 and a significant $(p<.0005)$ sphericity test suggesting that the assumed identity data matrix of the null hypothesis should be rejected and a PCA accordingly performed. Only two principal components with initial eigenvalues $\geq 1.0$ were extracted suggesting that the PCA constructed two principa components from the survey items based on eigenvalues. An eigenvalue is a ratio of the shared variance to the unique variance accounted for in the construct of interest by each factor obtained from the extraction by principal components Eigenvalues of 1.0 or greater are an arbitrary criterion accepted to help decide if a factor should be further interpreted or not. Extraction of the two components with cumulative explained variance of $68.33 \%$ suggests that a two factor solution would be adequate for the study.

The un-rotated factor loadings of the PCA (data not shown) showed that most of the dependent variables had high positive or negative loadings $(r>.70)$ on PC1 Apart from dehydrogenase activity (DHA) and fungal count (LOG10FC) which had moderate negative and positive loadings respectively on PC2, other variables had low positive and low negative loadings on PC2. Our reproduced correlations (data not shown) revealed small residuals indicating that there was very little difference between the reproduced correlations from the two extracted components and the actual correlations observed between the variables. This suggests that the 2 factor solution could provide an accurate summary of the relationships in the data.

The two component matrices rotated by Varimax with Kaiser Normalization through angles of $34.51^{\circ}(\mathrm{PC} 1)$ and $55.53^{\circ}$ (PC2) revealed that only LOG10BC, SMB-C and ALPA had high positive loadings on PC1 and low loadings on PC2 while LOG10FC had a high positive loading on PC2 but low loading on PC1. The effect of rotation is to spread the importance or contribution more or less equally between the two extracted principal components. A close observation of the right side of Table 2 reveals that the eigenvalues of the rotated factors had been spread between the two components as 3.817 and 2.333 for PC1 and PC2 respectively, compared to 5.141 and 1.009 in the initial solution. The $68.33 \%$ cumulative variability was accordingly distributed; $42.41 \%$ for PC1 and $25.92 \%$ for PC2 compared respectively to $57.11 \%$ and $11.21 \%$ in the initial solution Variable membership of PC1 included SOC, TN, AvP and LOG10FC while PC2 contained DHA, ALPA, BGA, LOG10BC and SMB-C. This result agrees with those of Jia et al. (2010) where they obtained three principal components with available phosphorus and organic matter extracted into one component. Our results showed that all members within a principal component were positively correlated among each other but correlated negatively with every other variable from another component.

The study confirmed the two factor solution of PCA with hierarchical cluster analysis (HCA) using Euclidean distance. The dendrogram showed that all the nine tested variables could be classified into two clusters with similar membership to that of PCA; a confirmation of the reliability of the PCA results. Firdous et al. (2016) reported excellent results using similar approaches in their study on soil quality parameters in Rawal Lake watershed. Our observations show that both component extraction and variable clustering were performed on the basis of variable relationship to soil microbial biomass-carbon. Variables in PC $1 /$ cluster 1 were all negatively correlated to SMB-C but the variables that shared PC 2/cluster 2 with SMB-C were all positively correlated.

A one-way multivariate analysis of covariance (MANCOVA) was conducted on data to ascertain the main effect of soil type on the nine moderately correlated dependent variables (DVs). The homogeneity of covariance assumption was violated; however, that of homogeneity of error variance was met. This enabled the interpretation of the multivariate test by Pillai's Trace instead of the frequently reported Wilks' $\lambda$ test. This test is reported as the most robust of all multivariate test because it could accommodate MANCOVA analysis when the homogeneity test of equality of covariance; the Box M test, is violated. The statistically significant effect of the covariate on the combined DVs suggests that the covariate adjusted values of the outcome, however, the main effect of soil type on the combined DVs was still statistically significant when controlling for the covariate. These results simply imply that the different soil types affected the response variables and that planting/sampling period could also adjust whatever influence soil type had on those responses.

The tests of between-subjects effect showed that sampling/planting period did not adjust the effects of soil type for Avp, DHA, BGA and LOG10FC indicating that whatever outcome was observed was purely due to differences in soil type. Bonferoni's test; the most robust and discriminating post hoc multiple comparison tests was used to separate significant means. The test revealed that no significant difference $(p=.448>.05)$ in mean SOC levels existed between control soil (CON) and NPK-treated polluted soil (POT) indicating that fertilizer application could improve SOC content of the cement dust polluted soil. The non-significant difference in TN between CON and POT $(p=.761>.05)$ and POT and POL $(p=.276>.05)$ indicate improvement of mean TN content by fertilizer application on cement dust polluted soil. Mean difference in available phosphorus (AvP) between CON and POT was not significant but significant difference existed between POT and POL and between CON and POL indicating respectively the effect of fertilizer application and the impact of cement dust pollution. Previous study by Ibanga et al. (2008) showed that cement dust pollution does significantly influence the chemical properties of Calabar soils. Mean alkaline phosphatase activity (ALPA) was significantly different between all soil type pairs suggesting that fertilizer treatment had little or no effect on this important soil activity. Bonferroni multiple comparison result also showed that mean $\beta$-glucosidase activity (BGA) and mean bacterial population (LOG10BC) differed significantly between CON and POL and between CON and POT but not between POT and POL suggesting that the fertilizer treatment only slightly improved these variables in the cement polluted soil but the improvements were still a long way off those in control soil. Lastly, mean difference in soil microbial 
biomass-carbon (SMB-C) was significant between CON and POL underlining the impact of cement dust on the variable. However, no significant difference existed between CON and POT ( $p=.062>.05)$ or between POT and POL $(p=1.000>$ $.05)$ indicating the effectiveness of fertilizer treatment in improving total soil microbial biomass-carbon (SMB-C) content

The ANCOVA analysis of corn yield revealed that yield did not differ significantly with planting period but with soil type, $F(2,32)=21.54, p<.0005$ model adjusted $r^{2}=.534$. This model could only explain $53.4 \%$ of the variations in the data suggesting that a lot of variations have been left unexplained. This is clearly due to the attempts made to meet most of the assumptions of this important statistical tool. It is actually because the planting periods of corn in Southern Nigeria do not significantly influence yield, that the region is known for an almost all-year round supply of the product. The significant mean difference in corn yield between CON and POL as well as that between CON and POT presented by Bonferroni multiple comparisons indicated that cement dust pollution significantly reduced corn yield and that fertilizer amendment of the polluted soil could not significantly reduce the impact of cement dust on the agricultural soil. Relative to the control soil, per cent loss in corn yield was $55.69 \%$ in un-amended cement dust-polluted soil but the loss reduced to $36.07 \%$ in NPK-treated polluted soil.

\section{CONCLUSION}

Principal component analysis (PCA) extracted two principal components, PC1 and PC2, from the nine dependent variables (DVs) which explained $68.33 \%$ variability about the data. Members within each component correlated positively with one another but negatively with members of the second component. The number and membership of extracted components were confirmed by the dendrogram of hierarchical cluster analysis (HCA) which presented two clusters. Significantly, component extraction and variable clustering were performed on the basis of variable relationship to soil microbial biomass-carbon (SMB-C). A one-way multivariate analysis of covariance (one-way MANCOVA) established significant main effect of soil type on the DVs after controlling for sampling period as covariate. The test of between-subjects effect showed that mean values of fungal population and dehydrogenase activity were not significantly affected by cement dust pollution or fertilizer treatment of the agricultural soils. Relative to control soil, per cent loss in corn yield was $55.69 \%$ in untreated cement dustpolluted soil but reduced to $36.07 \%$ in fertilizer-treated-polluted soil. The analysis has shown that cement dust pollution significantly reduced corn yield and that fertilizer amendment of polluted soil has little potential to reduce the impact and restore the fertility of cement dust polluted soil for high productivity.

\begin{abstract}
Acknowledgements: The authors acknowledge the efforts of Mr. Gift Abang (undergraduate student) and Mr. Reuben Tiku (Postgraduate student) for helping out in the laboratory and corn farms throughout the study period. The technical efforts of Prof. Ani Nkang and Prof. Timothy Owolabi, both of the Department of Plant and Ecological Studies are highly appreciated. The royal family of Dr. Etim Asuquo of Akampka, Nigeria is appreciated for their donation of land for the control studies.
\end{abstract}

\section{Conflict of Interest: None declared}

\section{REFERENCES}

ADETUNJI, A. T., LEWU, F. B., MULIDZI, R., \& NCUBE, B. (2017). The biological activities of $\beta$-glucosidase, phosphatase and urease as soil quality indicators: a review. J. Soil Sci. Plant Nutr. 17, 794-807. https://dx.doi.org/10.4067/S0718-95162017000300018

AKONGWUBEL, A. O., EWA, U. B., PRINCE, A., JUDE, O., MARTINS, A. SIMON, O., \& NICHOLAS, O. (2012). Evaluation of agronomic performance of maize (Zea mays $L$.) under different rates of poultry manure application in an ultisol of Obubra, Cross River State, Nigeria, Int. J. Agric. For., 2, 138-144.

AKPAN, J. F., AKI, E. E., \& ISONG, I. A. (2017). Comparative assessment of wetland and coastal plain soils in Calabar, Cross River State. Global J. Agric. Sci., 16: 17-30. http://dx.doi.org/10.4314/gjass.v16i1.3

AKPAN-IDIOK, A. U., \& OGBAJI, P. O. (2013). Characterization and classification of Onwu River floodplain soils in Cross River State, Nigeria. Int. J. Agric. Res., 8: 107-122. http://dx.doi.org/10.3923/ijar.2013.107.122.

ALEF, K., NANNIPIERI, P., \& TRAZAR-CAPEDA, C. (1998). Phosphatase activity, in: ALEF, K., NANNIPIERI, P. (Eds.), Methods in applied soil microbiology and biochemistry, Academic Press, Harcourt Brace \& Company, Publishers, London, pp. 335-344.

BACMAGA, M., BOROWIK, A., KUCHARSKI, J., TOMKIEL, M., \& WYSZKOWSKA, J. (2015). Microbial and enzymatic activity of soil contaminated with a mixture of diflufenican + mesosulfuron-methyl + iodosulfuron-methyl-sodium. Environ. Sci. Pollut. R. 22, 643-656. https://dx.doi.org/10.1007/s11356-014-3395-5

BAILEY, V. L., PEACOCK, A. D., SMITH, J. L., \& BOLTON JR, H. (2002) Relationship between soil microbial biomass determined by chloroform fumigation-extraction, substrate-induced respiration, and phospholipid fatty acid analysis. Soil Biol \& Biochem. 34: 1385-1389.

BAYHAN, Y., YAPICI, S., KOCAMAN, B., \& CAKICI, A. (2002). The effects of cement dust on some soil characteristics. Environ. Bull. 11, 1030-1036.

BENSON, N. U., ASUQUO, F. E., WILLIAMS, A. B., ESSIEN, J. P., EKONG, C. I., AKPABIO, O., \& OLAJIREO, A. A.( 2016). Source evaluation and trace metal contamination in benthic sediments from equatorial ecosystems using multivariate statistical techniques. PLoS ONE 11, e0156485. https://dx.doi.org/10.1371/journal.pone.0156485

BILEN, S. (2010). Effect of cement dust pollution on microbial properties and enzyme activities in cultivated and no till soils. Afr. J. Microbiol. Res. 4, 2418 2425 .

BIYIK, H. IMALI, A. ATALAN, E. TURENKCI, S., \& OGUN, E. (2005) Diversity of micro fungi in soil polluted by cement factory. Environ. Bull. 14, 130-137.

CASIDA JR., L. E., KLEIN, D. D., \& SANTORO, T. (1964). Soil dehydrogenase activity. Soil Sci. 98, 371-376. https://dx.doi.org/10.1097/00010694-196412000-00004

DAWES, L., \& GOONETILLEKE, A. (2006). Using multivariate analysis to predict the behaviour of soils under effluent irrigation. Water Air and Soil Pollut. 172, 109-127. https://dx.doi.org/10.1007/s11270-005-9064-Z

EIVAZI, F., \& TABATABAI, M. (1988). Glucosidases and galactosidase in soils. Soil Biol. Biochem. 20, 601-606.

https://dx.doi.org/10.1016/0038-0717(88)90141-1

EKPENYONG, M. ANTAI, S. ASITOK, A., \& EKPO, B. (2017a). Response surface modeling and optimization of major medium variables for glycolipopeptide production. Biocatal. Agric. Biotechnol. 10, 113-121. https://dx.doi.org/10.1016/j.bcab.2017.02.015

EKPENYONG, M. G., ANTAI, S. P., ASITOK, A. D., \& EKPO, B. O. (2017b) Plackett-Burman design and response surface optimization of medium trace nutrients for glycolipopeptide biosurfactant production. Iran. Biomed. J. 21, 249260. https://dx.doi.org/10.18869/acadpub.ibj.21.4.249

EKPENYONG, M. G., \& ANTAI, S. P. (2007a). Influence of pH on cadmium toxicity to species of Bacillus (02 and 12) during biodegradation of crude oil. Int. J. Biol. Chem., 1, 29-37. http://dx.doi.org/10.3923/ijbc.2007.29.37

EKPENYONG, M. G., \& ANTAI, S. P. (2007b). Cadmium toxicity on species of Bacillus and Pseudomonas during growth on crude oil. Trends Appl. Sci. Res. 2, 115-123. https://dx.doi.org/10.3923/tasr.2007.115.123

EKPENYONG, M. G., ANTAI, S. P., ESSIEN, J. P., \& IWATT, G. D. (2007a) $\mathrm{pH}$-dependent zinc toxicity differentials in species of Penicillium and Rhodotorula during oil biodegradation. Int. J. Biol. Chem. 1, 54-61. http://dx.doi.org/10.3923/ijbc.2007.54.61

EKPENYONG, M. G., ANTAI, S. P., \& ESSIEN, J. P. (2007b). Quantitative and qualitative assessment of hydrocarbon degrading bacteria and fungi in Qua Iboe Estuary, Nigeria. Res. J. Microbiol. 2, 415-425. https://dx.doi.org/10.3923/jm.2007.415.425

FEDERAL DEPARTMENT OF AGRICULTURAL LAND RESOURCES (FDALR) (1990). Soil report: the reconnaissance soil survey of Nigeria. 4, Jos: Chukason Nigeria Limited.

FERNANDEZ-MOYA, J., ALVARADO, A., MORALES, M., MIGUELAYANZ, A. S., \& MARCHAMALO-SACRISTAN, M. (2014). Using multivariate analysis of soil fertility as a tool for forest fertilization planning, Nutr. Cycl. Agroecosyst. 98, 155-167. https://dx.doi.org/10.1007/s10705-0149603-3

FIRDOUS, S., BEGUM, S., \& YASMIN, A. (2016). Assessment of soil quality parameters using multivariate analysis in the Rawal Lake watershed, Environ. Monit. Assess. 188, 533. https://dx.doi.org/10.1007/s10661-016-5527-5

Food and Agriculture Organization Statistical (FAOSTAT) Yearbook, (2014).

FRANCL, L. J. (1993). Multivariate analysis of selected edaphic factors and their relationship to Heterodera glycines population density. J. Nematol. 25, 270-276.

GORDON, C., DARKO, E.O., ADDO, M. A., \& NYARKO, B. J. B. (2013). Contamination of soils and loss of productivity of cowpea (Vigna unguiculata) caused by cement dust pollution. Int. J. Res. Chem. Environ. 3, 272-282.

HAGMANN, D. F., GOODEY, N. M., MATHIEU, C., EVANS, J., ARONSON, M. F. J., GALLAGHER, F., \& KRUMINS, J. A. (2015). Effect of metal contamination on microbial enzymatic activity in soil. Soil Biol. Biochem. 91, 291-297. https://dx.doi.org/10.1016/j.soilbio.2015.09.012

HEMIDA, S. K. (2005). Fungal and Bacterial populations in cement-incorporated soil. Int. J. Agric. Biol. 7, 158-161.

IBANGA, J., LEKWA, J., EKOO, L., ANNON, U. C., UDO-ISONG, M. N., UGWU T. T. O., \& AHUMILE, C. (1989). Soil and land use survey of cross river state. Cross River State Ministry of Agriculture and Natural Resources/ Main Bulk Trade Investment, Calabar, Nigeria.

IBANGA, I. J., UMOH, N. B., \& IREN, O. B. (2008). Effects of cement dust on soil chemical properties in Calabar environment, southeastern Nigeria. Comm. $\begin{array}{lllll}\text { Soil Sci. } & \text { Plant } & \text { Anal. } & \text { 551-558 }\end{array}$ https://dx.doi.org/10.1080/00103620701826829

ICHIKOGU, V. I. (2012). Total nitrogen and available phosphorus dynamics in soils regenerating from degraded abandoned rubber plantation in Orogun area of 
the rainforest zone of Southern Nigeria. Ethiopian J. Environ. Studies Manage. 5, 92-99

JANSSEN, E. (2003). Determination of total phosphorous, total nitrogen and nitrogen fractions. Desk Study 16, Project Horizontal-Inorg.

JIA L., WANG, W., LI, Y., \& YANG, L. (2010). Heavy metals in soil and crops of an intensively farmed area: a case study in Yucheng City, Shandong Province, China. Int. J. Environ. Res. Public Health 7, 395-412. https://dx.doi.org/10.3390/ijerph7020395

JUHOS, K. SZABO, S., \& LADANYI, M. (2015). Influence of soil properties on crop yield: a multivariate statistical approach. Int. Agrophys. 29, 433-440. https://dx.doi.org/10.1515/intag-2015-0049

KATSEANES, C. K., CHAPPELL, M. A., HOPKINS, B. G., DURHAM, B. D. PRICE, C. L., PORTER, B. E., \& MILLER, I. F. (2017). Multivariate soil fertility relationships for predicting the environmental persistence of 2,4,6 trinitrotoluene (TNT) and 1,3,5-trinitro-1,3,5-tricyclohexane (RDX) among taxonomically distinct soils. J. Environ. Manage. 203, 383-390. https://dx.doi.org/10.1016/j.jenvman.2017.08.005

KAUR, B., GUPTA, S. R., \& SINGH, G. (2000). Soil carbon, microbial activity and nitrogen availability in agroforestry systems on moderately alkaline soils in northern India. Appl. Soil Ecol. 15, 283-294. https://dx.doi.org/10.1016/S09291393(00)00079-2

KULANDAIVEL, S., NAGARAJAN, S., PRIYANGA, A. SARAVANAPANDIAN, R., \& THANGARANI, A. (2015). Effect of cement dust pollution on microbial properties and alkaline phosophatase enzyme activity in soil. Int. J. Curr. Microbiol. Appl. Sci. 4, 641-649.

LANDON, J. R. (1991). Booker tropical soil manual: Handbook for soil survey and agricultural land evaluation in the tropics and subtropics. Edinburgh Booker Tate Limited,

McCARTHY, G., SIEBIELEC, G., \& STUCZYNSKI, T. (2003). Response of soil microbiological activities to cadmium, lead and zinc salt amendments. $J$. Environ. Qual., 32, 1364-1355.

McLEOD, S. (1973). Studies on wet oxidation procedures for the determination of organic carbon in soils. CSIRO Division of Soils, Notes on Soil Techniques, pp.73-79.

NALINI, P., PRABHAKAR, T., ELLAIAH, P., \& GIRIJASANKAR, G. (2014) Isolation of alkaline phosphatase producing bacteria employing a novel screening medium for phosphatases. J. Pure Appl. Microbiol. 8, 3237-3244.

NOWAK, J., SZYMCZAK, J., \& SLOBODZIAN, T. (2003). The test of qualification $50 \%$ threshold of toxicity doses of different heavy metals for soil Soil Sci. 492, 242-248.

OCAK, I., SULUN, Y., \& HASENEKOGBU, I. (2004). The effect of cement dust emitted from Gaciantep cements plant on micro fungus flora of surrounding soils. Trakya Univ. J. Sci. 5, 107-115.

OLANIYAN, A. B., \& LUCAS, E. O. (2004). Maize hybrids cultivation in Nigeria - a review, J. Food Agric. Environ., 2, 177-181.

OLIVEIRA, I. A., JUNIOR, J. M., CAMPOS, M. C. C., AQUINO, R. E., \& FERRAUDO, A. S. (2017). Multivariate technique for determination of soil pedoenvironmental indicators in Southern Amazonas. Acta Sci. Agron. 39, 99 108. https://dx.doi.org/10.4025/actasciagron.v39i1.30763

OLSEN, S. R., COLE, C. V., WATANABE, F. S., \& DEAN. L. A. (1954) Estimation of available phosphorus in soils by extraction with sodium bicarbonate. USDA circular No. 939.

PANETTIERI, M., LAZARO, L., LOPEZ-GARRIDO, R., MURILLO, J. M., \& MADEJON, E. (2013). Glyphosate effect on soil biochemical properties under conservation tillage. Soil Till. Res. 133, 16-24. https://dx.doi.org/10.1016/j.still.2013.05.007

SADDIQUE, R. (2014). Utilization of industrial by-products in concrete Procedia Eng. (2nd International Conference on sustainable Civil Engineering

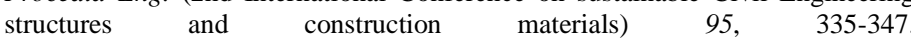
https://dx.doi.org/10.1016/j.proeng.2014.12.192

SALAZAR, S., SANCHEZ, L., ALVAREZ, J., VALVERDE, A., GALINDO, P., IGUAL, J., PEIX, A., \& SANTA-REGINA, I. (2011). Correlation among soil enzyme activities under different forest system management practices. Ecol. Eng. 37, 1123-1131. https://dx.doi.org/10.1016/j.ecoleng.2011.02.007

SAMEC, P. VAVRÍCEK, D. ŠIMKOVÁ, P., \& PŇ́ČEK，J. (2007). Multivariate statistical approach to comparison of the nutrient status of Norway spruce (Picea abies [L.] Karst.) and top-soil properties in differently managed forest stands. J. Forest Sci. 53, 101-112. https://dx.doi.org/10.17221/2173-JFS

SHINDE, R., CHIKODE, P., NIKAM, G., SUPALE, A., \& SABALE, S. (2016) Multivariate statistical analysis of soil parameters to establish baseline level around proposed Jaitapur Nuclear Power Plant (JNPP), Maharashtra, India. Int. J. Environ. Sci. Nat. Res. 1, 555557.

SILVA, S. A., \& LIMA, J. S. S. (2012). Fertility of a humic rhodic hapludox under coffee cultivation. R. Bras. Ci. Solo 36, 467-474. https://dx.doi.org/10.1590/S0100-06832012000200016.

STEGE, P. W., MESSINA, G. A., BIANCHI, G., OLSINA, R. A., \& RABA, J. (2010). Determination of $\beta$-glucosidase activity in soils with a bio-analytica sensor modified with multi-walled carbon nanotubes. Anal. Bioanal. Chem. 397, 1347-1353. https://dx.doi.org/10.1007/s00216-010-3634-7
TABACHNICK, B. G., \& FIDELL, L. S. (1996). Using Multivariate Statistics New York, Harper Collins College Publishers

TEMPLERA, P. FINDLAY, S., \& LOVETT, G. (2003). Soil microbial biomass and nitrogen transformations among five tree species of the Catskill Mountains Soil Biol. Biochem. 35, 607-613. https://dx.doi.org/10.1016/S0038 0717(03)00006-3

UNDIE, U. L., UWAH, D. F., \& ATTOE, E. E. (2012). Growth and development of late season maize/soybean intercropping in response to nitrogen and crop arrangement in the forest Agro-ecology of South Southern Nigeria, Int. J. Agric. Res., 7, 1-16. https://dx.doi.org/10.3923/ijar.2012.1.16

VANCE, E. D., BROOKS, P. C., \& JENKINSON, D. S. (1987). An extraction method for measuring soil microbial biomass-C. Soil Biol. Biochem., 19: 703 707

VINHAL-FREITAS, I. C., WANGEN, D. R. B, FERREIRA, A. S., CORREA, G. F., \&WENDLING, B. (2010). Microbial and enzymatic activity in soil after organic composting. R. Bras. Ci. Solo. 34, 757-764 https://dx.doi.org/10.1590/S0100-06832010000300017

WOLINSKA, A., \& STEPNIEWSKA, Z. (2012). Dehydrogenase activity in the soil environment. In. R.A. CANUTO, (Ed.), Dehydrogenases. Rijeka, INTECH Publisher. https://dx.doi.org/10.5772/48294

ZERROUQI, Z., SHAA, M., OUJIDI, M., ELJARMOUZ, M., BENGAMRA, S., \& ZERROUQI, A. (2008). Assessment of cement dust impact on soil using principal component analysis and GLS. Int. J. Environ. Sci. Technol., 591, 125134. https://dx.doi.org/10.1007/BF03326005 